\title{
The analytic hierarchy process for selection of suitable trees for Mexico City
}

\author{
Juan Carlos Bravo-Bello ${ }^{(1)}$, \\ Tomás Martínez-Trinidad (1), \\ Martín Enrique Romero-Sanchez ${ }^{(2)}$, \\ José René Valdez-Lazalde ${ }^{(1)}$, \\ Héctor Benavides-Meza ${ }^{(2)}$
}

\begin{abstract}
Urban foresters require methodologies that help to select tree species for urban environments, mainly in places where there is a large number of potential species such as the Valley of Mexico. We applied the Analytic Hierarchy Process (AHP) to select suitable native tree species that are under-represented or non-existent in Mexico City trees. Through bibliographic research, the selection criteria and the list of trees to be evaluated were selected; later, a group of specialists in urban forestry and arboriculture determined by pair-wise comparison matrices the specific weight of each selection criterion, while a set of taxonomists evaluated the rating of each attribute for each species. Finally, for practical purposes, the synthesis of both evaluations resulted in a ranking of 15 tree species according to their degree of aptitude suggested for Mexico City. According to results, Buddleja cordata, Quercus glaucoides and Litsea glaucescens obtained the highest degree of suitability as a large, medium and small-size species, respectively. The AHP proved to be an appropriate methodology to solve a complex problem through multiple criteria evaluation by diverse specialists in the subject. The implementation of the results contributes to the selection process of suitable tree species for urban environments.
\end{abstract}

Keywords: Multi-criteria Analysis, Native Species, Urban Environment, Urban Tree Diversity, Valley of Mexico.

McPherson 1997), habitat, generation of feelings of well-being among people (UIrich 1986), and biodiversity and carbon sequestration (Chiesura 2004, Wang et al. 2015). However, there is a need to select suitable tree species under the proposed "10-20-30 rule" which establishes not to exceed $10 \%$ of a single species, $20 \%$ of the same genus, and $30 \%$ of the same family in an urban forest to promote the tree benefits (Santamour 1990).

In many cities, one of the essential components of the urban structure is green areas, and different studies have been carried out to determine the most suitable tree species (Mizerit 2006, Benavides et al. 2011). For example, a great diversity of species has been recorded in Mexico city (50 botanical families, 94 genera and 181 different species - Mizerit 2006, Martínez 2008, Benavides et al. 2011); however, most species are represented by just a small number of individuals and predominating are those of exotic origin, particularly of the genera Ficus, Jacaranda, Casuarina and Ligustrum (Benavides et al. 2011). Benavides (1992) reported that about $70 \%$ to $72 \%$ of tree species in Mexico City are exotic, and about $28-30 \%$ are native species of the Valley of Mexico. Although many exotic species may have higher possibilities to tolerate changing climatic conditions compared to native species (Easterling et al. 2000); a most efficient provision of ecosystem services has been recorded when there is an adequate proportion of both native and exotic species (Nielsen et al.
2014) with higher resistance and resilience to adverse factors (Clark et al. 1997, Morgenroth et al. 2016).

An appropriate selection process that incorporates expert's opinions, the available scientific information, and the conditions of the plantation site is fundamental to avoid conflicts in the future, extend the tree life, and maximize tree benefits (Pauleit 2003, Li et al. 2011, Asgarzadeh et al. 2014). However, in many cities, the selection of tree species relies on the personnel in charge of reforestation and the availability of the plant material in the nearby nurseries, without taking into account the sizeable local tree diversity associated with the urban site conditions and technical recommendations (PAOT 2003, Chacalo et al. 1997). Similarly, the personnel usually lack a list of suitable tree species or a methodology that incorporates most of the essential criteria for species selection such as environmental resistance, stress tolerance, economic viability, functional quality, and aesthetical aspects, among others (Sjöman \& Nielsen 2010, Asgarzadeh et al. 2014, Conway \& Vander Vecht 2015).

The Analytical Hierarchical Process (AHP) is a multicriteria analysis technique that breakdown multiple datasets in a pair-wise comparison matrix, which is used to calculate the geometric mean and normalized weight of parameters parts to support complex decision making such as the selection of suitable trees in urban areas (Saaty 1987, Li et al. 2011, Asgarzadeh et al. 2014). This technique incorporates the expert's 



Legend

Urban Area of Mexico City State boundary

Layers Credit: Esri, Digital Globe, GeoEye,
Earthstar Geographics, CNES/Airbus DS, USDA, USGS, AeroGRID, IGN, Garmin, Intermap, OpenStreetMap c
the GIS User Commnunity

Fig. 1 - Urban area of Mexico City.

experience with scientific information to make the final decision more robust. The AHP has been used in a wide variety of re search to address different problems, including forestry, resource management and monitoring plants in national parks (González et al. 2016). Recently, the use of AHP has been suggested for urban tree selection because the process involves a combination of several factors (criteria), each with a different degree of importance on the final decision (Asgarzadeh et al. 2014). Previous research suggests implementing criteria such as tolerance to stress factors, aesthetics, maintenance, growth characteristics, and ecological effects, among others to guide species selection (Amir \& Misgav 1990, Miller 1997, GDF 2000, Pauleit 2003, Sæbø et al. 2003) but the decision making can be complex. The AHP has been recommended as an inte- grated assessment approach that considers the complexity of multiple criteria in tree selection for urban areas such as Hefei, China and Tehran, Iran (Li et al. 2011, Asgarzadeh et al. 2014). The tree selection process emphasizes when there is a large number of potential urban species to select. Therefore, this study adapts the Analytic Hierarchy Process (AHP) for the selection of suitable native tree species for Mexico City.

\section{Methods}

\section{Study area}

Mexico City's territory is divided into urban land (UL) with an area of 60,867.9 ha and conservation land (CL) with 87,294.4 ha (Fig. 1) and is part of the Valley of Mexico. This study comprises only the urban area of Mexico City.

\section{Analytic Hierarchy Process (AHP)}

A conventional four-level hierarchy model was constructed to integrate all the AHP stages properly. In the first level, the overall objective of the process was established. In the next level, the selection of the most critical criteria to solve the main problem were selected. In the third level, each criterion was broken down into a series of subordinate criteria or subcriteria to provide further specificity to the resolution of the problem. Finally, the last level identified the alternatives (tree species) to be evaluated for planting purposes in an urban environment. The purpose of breaking down the problem into four stages is to analyze in an isolated manner all the elements that contribute to its resolution (Fig. 2).

\section{First level: determination of the overall} objective

The first level of the decision-making process was the selection of small, medium and large native trees suitable for urban conditions of Mexico City. This level was determined based on the configuration of the urban landscape with a small dominating number of species, the large number of native species growing in natural conditions of the Valley of Mexico, and the recommendation of increasing native species on the urban plant selection (Mizerit 2006, Martínez 2008, Benavides et al. 2011).

\section{Second and third levels: determination of selection criteria and subcriteria} Criteria and subcriteria were based on previous research on the selection of trees for urban environments (Amir \& Misgav 1990, Miller 1997, GDF 2000, Pauleit 2003 , Sæbø et al. 2003, Li et al. 2011, Asgarzadeh et al. 2014). The most recommended subcriteria were selected giving a total of 31 subcriteria, three of which were incorporated for particular characteristics relevant to Mexico City: (i) retention of suspended particles; (ii) low volatile organic compound (VOC) emissions; and (iii) reduced soil volume tolerance. Then, the 31 subcri-



Fig. 2 - Structure of the hierarchy for Mexico City tree species selection. (1): Drought resistance; (2): Hightemperature resistance; (3): Low-temperature resistance; (4): Pest and disease resistance; (5): Salinity resistance; (6): Air pollution tolerance; (7): Wind tolerance; (8): Soil compaction tolerance; (9): Shade tolerance; (10): Poor soil tolerance; (11): Ability to retain suspended particles; (12): Noise absorption; (13): Plant palette diversification; (14): Microclimate regulation; (15): Visual beauty; (16): Lifespan; (17): Plasticity; (18): Growth rate; (19): Suitability for restrictive soil volumes; (20): Non-aggressive rooting systems; (21): Species with low VOC emissions; (22): Phenology (Deciduous/Perennial); (23): Resistance to limb breakage; (24): Flowering and fruiting; (25): Fragrance; (26): Foliage color; (27): Crown shape; (28): Bark texture; (29): Establishment costs; (30): Maintenance costs; (31): Disposal costs. (A to O): Species evaluated for Mexico City's green areas. 
teria were grouped into six criteria (Tab. 1).

\section{Weighting of criteria and subcriteria}

The relative weights of both criteria and subcriteria were estimated by assigning them numerical values of the so-called fundamental scale of absolute numbers (1-9), based on the degree of importance they have on the decision (Saaty 1990). For the above, the opinion, preferences, or judgments of 17 out of 20 professionals were considered. They were selected based on their expertise in urban forestry and arboriculture. The opinions were collected by a survey design following the format described by Malczewski (1999) and OlivasGallegos et al. (2007), consisting of seven questionnaires. The participants indicated their level of preference for one criterion or sub-criterion over another through independent comparisons between pairs of elements of level two and similar for level three of the hierarchy, choosing a value between one and nine on the fundamental scale proposed by Saaty (1987). The use of this scale is one of the central points of the methodology. It allows to transform qualitative aspects into quantitative, eliminates ambiguities generated when comparing very close elements, is based on the natural tendency to compare only two elements at the same time, and provides an adequate interval that allows a clear distinction to be made between the different levels of intensity of the preference of one judgment over another (Malczewski 1999, Saaty 1987).

In the case of the criteria, each one was compared against the remaining criteria and for the subcriteria, the comparisons were made only between the elements within each criterion, i.e., subcriteria of different criteria were not compared ( $\mathrm{Li}$ et al. 2011). To analyze the questionnaires, they were transformed into comparison matrices that were entered in the GIS Analysis/ Decision Support/Weight module of the IDRISI ${ }^{\circledast}$ Selva software (López-Upton et al. 2015, González et al. 2016). The respective weights were obtained for the criteria and subcriteria from each participant (Tab. 2) answering the seven questionnaires.

From the previous procedure, the consistency index was calculated to determine the strength of the comparisons made by the participants and to validate that the judgments do not have errors, nor contradictions among them. Based on the result of this index for each questionnaire, only those whose result was equal to or less than 0.10 were considered as recommended by Saaty (1987). Finally, to obtain the definitive weight of the criteria and subcriteria, the arithmetic mean of the values from all the questionnaires was taken (Asgarzadeh et al. 2014, González et al. 2016).

Fourth level: species determination A total of 13 bibliographic sources were reviewed to identify the taxonomic tree diversity near Mexico City (Valley of Mexico),

Tab. 1 - Criteria and subcriteria used to guide Mexico City tree species selection. (1): Asgarzadeh et al. 2014; (2): Li et al. 2011; (3): Amir \& Misgav 1990; (4): Miller 1997; (5): Sæbø et al. 2003; (6): Pauleit 2003; (7): GDF 2000.

\begin{tabular}{|c|c|c|}
\hline Criteria & Subcriteria & Source \\
\hline \multirow[t]{5}{*}{ Environmental } & 1. Drought tolerance & $1,2,6,7$ \\
\hline & 2. High temperature resistance & $1,2,6,7$ \\
\hline & 3. Low temperature resistance & $1,2,6,7$ \\
\hline & 4. Pest and disease resistance & $2,5,6,7$ \\
\hline & 5. Salinity resistance & $1,6,7$ \\
\hline \multirow{5}{*}{$\begin{array}{l}\text { Urban } \\
\text { environment } \\
\text { tolerance }\end{array}$} & 6. Air pollution tolerance & $1,4,5,7$ \\
\hline & 7. Wind tolerance & $1,5,6$ \\
\hline & 8. Soil compaction tolerance & 6 \\
\hline & 9. Shade tolerance & 1,6 \\
\hline & 10. Poor soil tolerance & 1,2 \\
\hline \multirow[t]{5}{*}{ Functional } & 11. Ability to retain suspended particles & (new) \\
\hline & 12. Noise absorption & 3 \\
\hline & 13. Diversification of plant palette & 3,7 \\
\hline & 14. Microclimate regulation & 3 \\
\hline & 15. Visual beauty & 3 \\
\hline \multirow[t]{8}{*}{ Desirable species } & 16. Life span & $1,2,3,7$ \\
\hline & 17. Plasticity & 5 \\
\hline & 18. Growth rate & $1,2,3,5,7$ \\
\hline & 19. Suitability for restrictive soil volumes & (new) \\
\hline & 20. Non-aggressive rooting systems & 1,7 \\
\hline & 21. Species with low VOC emissions & (new) \\
\hline & 22. Phenology (deciduous/perennial) & $1,3,7$ \\
\hline & 23. Resistance to branch breakage & 2,5 \\
\hline \multirow[t]{5}{*}{ Aesthetics } & 24. Flowering and fruiting & $1,2,3,6,7$ \\
\hline & 25. Fragance & 1 \\
\hline & 26. Foliage color & $1,2,3,6$ \\
\hline & 27. Crown shape & $2,3,6$ \\
\hline & 28. Bark texture & $2,3,6$ \\
\hline \multirow[t]{3}{*}{ Economics } & 29. Establishment cost & 4 \\
\hline & 30. Maintenance cost & 4 \\
\hline & 31. Removal and cleanup cost & 4 \\
\hline
\end{tabular}

resulting in a total of 1851 species (Tab. 3). In the revision of the first list, repetition, exotic species and shrubs were cut off resulting in a new list with a total of 869 potential native tree species.

Subsequently, those species that ap- cies with an adjacent distribution to the

Tab. 2 - Example of a comparison matrix to determine the weight of the criteria for Mexico City tree species selection (consistency index $=0.1$ )

\begin{tabular}{|c|c|c|c|c|c|c|c|}
\hline Criteria & 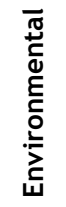 & 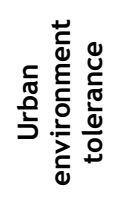 & 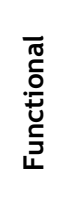 & 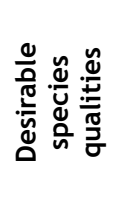 & 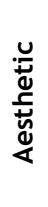 & 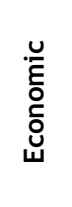 &  \\
\hline Environmental & 1 & 1 & $1 / 5$ & $1 / 7$ & 8 & 2 & 0.1169 \\
\hline Urban environment tolerance & 1 & 1 & 1 & $1 / 3$ & 3 & 1 & 0.1249 \\
\hline Functional & 5 & 1 & 1 & 1 & 8 & 3 & 0.2822 \\
\hline Desirable species qualities & 7 & 3 & 1 & 1 & 7 & 3 & 0.3511 \\
\hline Aesthetic & $1 / 8$ & $1 / 3$ & $1 / 8$ & $1 / 7$ & 1 & $1 / 5$ & 0.0288 \\
\hline Economic & $1 / 2$ & 1 & $1 / 3$ & $1 / 3$ & 5 & 1 & 0.0962 \\
\hline
\end{tabular}


Tab. 3 - Bibliographical sources to identify species with potential for tree diversification in Mexico City. (1): Calderon De Rzedowski \& Rzedowski 2005; (2): Olmedo \& Rocha 2004; (3): CONAFOR 2007; (4): Batis et al. 1999; (5): Benavides et al. 2011; (6): Guadarrama-Martínez et al. 2012; (7): Martínez 2008; (8): Chacalo \& Corona 2009; (9): GDF 2000; (10): Niembro 1990; (11): Rzedowski 2015; (12): Rzedowski \& Calderón De Rzedowski 2009.

\begin{tabular}{|llr}
\hline Source & Source topic & No. species \\
\hline 1,2 & Native tree species with adjacent distribution to the study area & 122,79 \\
\hline 3 & Tree species used for different purposes, mainly reforestation & 168 \\
\hline 4 & Native tree species of Mexico & 70 \\
\hline 5,7 & Frequent tree species in the green areas of Mexico City & 131,57 \\
\hline 6 & $\begin{array}{l}\text { Tree species with adjacent distribution to the study area and } \\
\text { ornamental potential }\end{array}$ & 65 \\
\hline 8 & Tree species recommended for cities & 27 \\
\hline 5,9 & Tree species recommended for Mexico City & 53,59 \\
\hline 10 & Tree species of Mexico & 300 \\
\hline 11,12 & Tree species with ecological affinity to the study area & 487,233 \\
\hline- & Total & 1851 \\
\hline
\end{tabular}

study area (listings 1 and 2) and for belonging to regions with ecological affinity to the area (listings 11 and 12). It was considered that these species could have a high potential to settle and survive under harsh conditions. This last procedure generated a list including 74 tree species; later, because the plantation spaces in the city are diverse in size, the species were categorized according to height, with those up to nine meters being considered as small, those from nine to 15 meters as medium-sized, and those more than 15 meters in height as large. Mature tree size is the first characteristic to consider based on the plantation site. Finally, the 15 most suitable species were selected to fulfill the purpose of this study; five from each height category. The final number of species were considered based on the required resources and time to qualify of all attributes for all the chosen species during the experts' evaluation step.

Evaluation of attributes and synthesis of results

The 15 selected tree species were evaluated (rated) on their suitability for planting by a group of six botanists specialized in the taxonomy and with experience in the

Valley of Mexico flora for the suggested attributes (subcriteria). The information was gathered through an evaluation format where the ratings were expressed based on a nine-level qualitative scale, with one assigned as the lowest value and nine the highest to rate the performance of the species about a specific attribute. For example, concerning the drought tolerance sub-criterion, taxonomists rated 7, 5 and 1 to Alnus jorullensis, Populus tremuloides and Clethra mexicana respectively, indicating with their evaluations that the former is more tolerant than the latter. Of the 2790 possible assignable ratings (31 subcriteria $\times$ 15 species $\times 6$ taxonomists), 2027 corresponded to complete qualifications of each attribute by all the botanists. From the 763 missing ratings, 279 corresponded to nine cases in which some specialists did not know the information about all the attributes in six species, so these ratings were not considered in the analysis. The remaining missing ratings (484) were assigned based on the other botanist answers with the statistical software $R$ through a Random Forest algorithm (Badler et al. 2004). As a result of this procedure, the required series of attribute ratings were obtained using the statistical

Tab. 4 - Relative weight of the most important criteria and subcriteria. (1): The estimated weight of the criteria is shown in descending order; (2): the subcriterion corresponds to the highest weight in each criteria group.

\begin{tabular}{llll}
\hline Criteria & Weight $^{(1)}$ & Subcriteria & Weight \\
\hline Environmental & 0.2576 & Pest and disease resistance & 0.3179 \\
\hline Urban environment tolerance & 0.2337 & Soil compaction tolerance & 0.3111 \\
\hline Functional & 0.1884 & Microclimate regulation & 0.3285 \\
\hline Desirable species qualities & 0.1791 & Non-aggressive rooting systems & 0.2019 \\
\hline Aesthetic & 0.0817 & Crown shape & 0.3342 \\
\hline Economic & 0.0596 & Maintenance costs & 0.6349 \\
\hline
\end{tabular}

mode as an estimator to obtain a single value that served as input for the analysis.

Finally, to obtain the final score that indicates the degree of suitability of the tree species for the conditions of Mexico City's urban environment, the following equation was used (eqn. 1):

$$
T_{i}=\sum_{i=1}^{n}\left(R_{i} \cdot r_{i} \cdot W_{i}\right)
$$

where $T_{i}$ is the total score of the species, $n$ is the total number of subcriteria, $R, r$ and $W$ are the weight of the criteria (determined by the pairwise comparisons), the weight of the subcriteria and the rating of the attribute $i$, respectively ( $\mathrm{Li}$ et al. 2011). The points are added to indicate the final selection priority of each of the species; therefore, the higher the score, the higher the degree of suitability for incorporation into Mexico City's trees.

\section{Results}

The AHP goal of this study was the selection of suitable native trees for planting in Mexico City conditions (first level). Among the six criteria (second level) involved in the selection of tree species, the opinion of the experts through the pair-wise questionnaires indicated that for Mexico City's conditions the most important one was the environmental. In the case of the 31 subcriteria (third level), pest and disease resistance, soil compaction tolerance, microclimate regulation, non-aggressive rooting systems, crown shape and maintenance costs result as the most important in each criteria group (Tab. 4).

The bibliographic research showed up a list of 74 potential species for Mexico City, but only 15 alternative species grouped by height were analyzed for ranking the suitability degree with the AHP approach (Tab. 5). From the 15 species (fourth level), only 10 obtained a score higher than five (Tab. 5); therefore, in general the five remaining species could be considered in a smaller proportion for incorporation into Mexico City's trees. After analyzing the scores obtained, it was decided to establish an arbitrary limit in order to issue the best possible recommendation, that is, that the suggested species have the best chance of surviving and establishing themselves according to the opinions issued by the various experts. Five species presented the highest scores: Buddleja cordata, Pinus leiophylla, Litsea glaucescens, Quercus glaucoides and Ceanothus caeruleus. After grouping the species according to their height (large, medium-sized and small), the results highlighted that the species in first place in each of the three size categories, all with a score higher than 5.6, were among the top five species.

\section{Discussion}

The AHP allowed the qualification of suitable native trees to be planted in green areas of Mexico City. The methodology facilitates the incorporation of bibliographical 
information, the experience of specialists, and a multicriteria approach to qualify the suitability of potential native species. Of the final 15 species analyzed, Buddleja cordata, Populus tremuloides and Clethra mexicana are already reported as part of the diversity of species that make up Mexico City urban forest (Mizerit 2006, Martínez 2008, Benavides et al. 2011); however, neither the number of specimens, genera, nor botanical families (Scrophulariaceae, Salicaceae and Clethraceae, respectively) are currently within the group of highly recommended species by literature. Therefore, their integration into the urban tree composition would be of great importance to avoid the small number of species that dominate the urban forest (Mizerit 2006, Benavides et al. 2011).

Species that tolerate stressful conditions such as Pinus leiophylla, Alnus jorullensis, Quercus glaucoides and Viburnum elatum are not reported in Mexico City, although the genus and families to which they belong (Pinaceae, Betulaceae, Fagaceae and Adoxaceae, respectively) are also represented with a small number of specimens. The species Litsea glaucescens is not also reported, nor are others of the same genus but the family (Lauraceae) is, so their incorporation would be useful regarding expanding the potential species for urban reforestation.

The introduction of the species llex tolucana, Garrya laurifolia, Berberis moranensis, Cornus disciflora, Ceanothus caeruleus, Rhamnus serrata and Ternstroemia lineata, at a reasonable scale into the Mexico City urban forest would contribute to its diversification given that neither species, genera nor botanical families (Aquifoliaceae, Garryaceae, Berberidaceae, Cornaceae, Rhamnaceae and Pentaphylacaceae, respectively) are reported as part of the current urban forest composition. This group of species can be the pioneers in the introduction of new native species, which is essential regarding the health of an urban ecosystem (Clark et al. 1997).

Species selection based on scores derived from the analysis of performance concerning specific criteria had a 6.44 rating as the highest score; however, the average was around 5.28 , so a threshold could be established for better management of species. For example, the species llex tolucana, Berberis moranensis, Cornus disciflora, Viburnum elatum and Ternstroemia lineata, which had scores lower than five, would be temporarily excluded from the recommendations. Therefore, before being able to implement the results of this research and rule out in advance species with low scores, it would be beneficial to incorporate species trials (Gazca \& Benavides 2012), a procedure that has already been used to evaluate other species under the trial and error approach.

Regarding the species that obtained the three highest scores, namely Buddleja cordata (6.44), Pinus leiophylla (5.90) and Lit-

Tab. 5 - Degree of the suitability of native species by height type using AHP, to be suggested in Mexico City's green areas.

\begin{tabular}{|c|c|c|c|}
\hline Height & No. & Species & Score \\
\hline \multirow{5}{*}{ 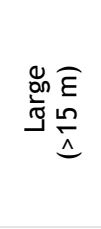 } & 1 & Buddleja cordata Kunth & 6.46 \\
\hline & 2 & Pinus leiophylla Schiede ex Schltdl. \& Cham. & 5.92 \\
\hline & 3 & Alnus jorullensis Kunth & 5.37 \\
\hline & 4 & Populus tremuloides Michx. & 5.02 \\
\hline & 5 & Ilex tolucana Hemsl. & 4.88 \\
\hline \multirow{5}{*}{ 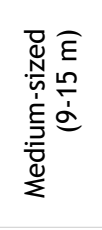 } & 1 & Quercus glaucoides M. Martens \& Galeotti & 5.67 \\
\hline & 2 & Garrya laurifolia Hartw. ex Benth. & 5.18 \\
\hline & 3 & Clethra mexicana DC. & 5.11 \\
\hline & 4 & Berberis moranensis Schult. \& Schult. f. & 4.95 \\
\hline & 5 & Cornus disciflora DC. & 4.85 \\
\hline \multirow{5}{*}{$\begin{array}{l}\overline{\bar{\sigma}} \widehat{\bar{E}} \\
\stackrel{E}{\sigma} \underset{v}{v}\end{array}$} & 1 & Litsea glaucescens Kunth & 5.75 \\
\hline & 2 & Ceanothus caeruleus Lag. & 5.40 \\
\hline & 3 & Rhamnus serrata Schult. & 5.34 \\
\hline & 4 & Viburnum elatum Benth. & 4.79 \\
\hline & 5 & Ternstroemia lineata DC. & 4.56 \\
\hline
\end{tabular}

sea glaucescens (5.74), the first one is widely distributed in the Valley of Mexico, in scrubland, grasslands and forests. It is commonly found naturally as part of the secondary vegetation, in severely disturbed places, including urban areas (Calderon De Rzedowski \& Rzedowski 2005). Buddleja cordata is a species of great ecological importance because it grows in shallow soils and tolerates low humidity (CastilloArgüero et al. 2009); this makes Buddleja cordata, a species with attributes appropriate to the conditions of the city, where the reduced planting spaces and lack of irrigation are prevalent.

The National Forestry Commission (CONAFOR 2007) reports important characteristics of Pinus leiophylla that need to be considered for incorporation into Mexico City's trees. For example, its wide altitudinal gradient (from 1600 to $3000 \mathrm{~m}$ a.s.l.), its recommendation in reforestation of degraded soils because of drought tolerance and ability to grow in low-depth soils, and a known protocol for its sexual and vegetative propagation; thus supporting the potential use of this species mainly in open spaces such as parks or gardens.

Litsea glaucescens obtained the thirdhighest rating, thus representing an excellent diversification alternative to the current tree species. The species is within the Official Mexican Standard NOM-059 (SEMARNAT 2010) under the category of endangered species because of its overexploitation without regulations due to multiple traditional uses such as medicinal, culinary and even religious (Dávila 2011). Therefore, Litsea glaucescens is one of the nontimber forest species with high development potential in Mexico City.

Among the critical points to consider to achieve a healthy urban forest, the species diversity is recognized as a crucial factor, mainly because experience has shown that in the face of specific pests and unusual climate patterns, one cannot depend on a single species (Clark et al. 1997). Four out of the 15 species evaluated in this research are endemic to Mexico (Buddleja cordata, Quercus glaucoides, Berberis moranensis and Viburnum elatum). Also, the species are naturally distributed adjacently in the region known as the Valley of Mexico (Calderon De Rzedowski \& Rzedowski 2005), in which Mexico City is located.

The use of the AHP approach emphasizes that the identification of appropriate criteria and subcriteria for species selection made necessary to incorporate all the actors involved in the different levels and stages of green area planning and maintenance (Li et al. 2011). Unfortunately, there is little knowledge of this technique in urban tree selection, but its applicability could improve the planning of maintenance activities in urban green areas that involve making decisions. The present study is important on a practical level since these criteria were weighted by specialists based on the conditions of Mexico City. Within the group of environmental subcriteria, pest and disease resistance obtained the highest score. Under limited diversity, the attack of a pest can spread rapidly causing severe damage to trees, as has happened with the red gum lerp psyllid (Glycaspis brimblecombei - GDF 2004), and recently with the mistletoe infestation reported in at least 17 species of ten different families (Arriola et al. 2013).

Within the subcriteria of tolerance to the urban environment, tolerance to soil compaction stood out as the one with the greatest weight; in fact, soil compaction is the main interference that occur between trees and urban infrastructure conditions and that creates problems in the medium and long-term (Chacalo et al. 1997). Soil compaction affects both the quality of tree 
life and of the site itself. The two species with the highest degree of tolerance to soil compaction according to the results were Buddleja cordata and Pinus leiophylla.

Finally, crown shape and maintenance costs turned up as the most crucial subcriteria of the aesthetic and economic criteria, respectively. Problems in this regard can be attributed to a lack of planning, training, budget and proper maintenance practices. Generally, the inappropriate selection of species to be planted results in establishing species with crowns that are mostly incompatible with the urban infrastructure, as they may, for example, interfere with aerial service lines, a problem that results in constant and poorly executed pruning, so-called topping, which leads to frequent expenses (Chacalo et al. 1997, PAOT 2003). A central point in this research was to classify the tree species according to their height; such consideration will allow making small trees such as Litsea glaucescens and Ceanothus caeruleus compatible with the planting space in terms of dimensions and existing infrastructure.

The incorporation of AHP into decision making gave different advantages over other methodologies for the selection of species in urban environments with the specific criteria for each case. For example, the weighting of criteria reflects the actual decision-making process in which each factor to be considered has a different degree of importance (Asgarzadeh et al. 2014). Besides, it allowed the incorporation of important bibliographic information and admitted the participation of specialists in the different areas involved ( $\mathrm{Li}$ et al. 2011), which is essential when the scientific literature is incomplete. The above characteristics allowed an evaluation of the alternatives with a grade that reflects their degree of aptitude for the task in question. Finally, due to the mathematical support behind the AHP process, the degree of subjectivity is reduced during the process of comparing the criteria and subcriteria involved (Osorio \& Orejuela 2008). The next step after using AHP in the selection of suitable tree species to Mexico City would involve the development of propagation studies and management plans.

\section{Conclusions}

The implementation of a multicriteria methodology (AHP) helps to adequately address the complex nature of selecting the most suitable tree from among a large number for some cities. The selection process contributes to the potential incorporation of an excellent availability of native species. Although most of the tree species evaluated in this work are not propagated at present, this should not be a constraint on promoting their use by local government and municipalities. Finally, the flexibility of this methodology could allow the combination with new criteria or tools to strengthen the results during its practical implementation.

\section{References}

Amir S, Misgav A (1990). A framework for street tree planning in urban areas in Israel. Landscape and Urban Planning 19: 203-212. - doi: 10.1016/0169-2046(90)90022-T

Arriola PVJ, Velasco BE, Hernández TT, González HA, Romero SME (2013). True mistletoes of the trees of Mexico City. Revista Mexicana de Ciencias Forestales 4 (19): 34-45. - doi: 10.29298/rm cf.v4i19.377

Asgarzadeh $M$, Vahdati $K$, Lotfi $M$, Arab $M$, Babaei A, Naderi F, Pir Soufi M, Rouhani G (2014). Plant selection method for urban landscapes of semi-arid cities (a case study of Tehran). Urban Forestry and Urban Greening 13: 450-458. - doi: 10.1016/j.ufug.2014.04.006

Badler CE, Alsina SM, Puigsubirá CR, Vitelleschi MS (2004). Información faltante en experimentos biológicos. Una solución mediante imputación múltiple a través del programa SAS [Missing information in biological experiments. A multiple imputation solution using the SAS program]. Revista FABICIB 8: 79-87. [in Spanish] - doi: 10.14409/fabicib.v8i1.736

Batis MAI, Alcocer SMI, Gual DM, Sánchez DC, Vázquez YC (1999). Arboles mexicanos potencialmente valiosos para la restauración ecológica y la reforestación [Potential valuable Mexican trees for ecological restoration and reforestation]. Website. [in Spanish] [online] URL: http://www.gbif.org/dataset/b79971eb-bd50-4e c3-a922-778ac3fozeoc

Benavides MHM (1992). Current situation of the urban forest in Mexico City. Journal of Arboriculture 18 (1): 33-36. [online] URL: http://www. semanticscholar.org/paper/a783363c249b539d ob6c8fa6cda32c53e5635fcc?p2df

Benavides MHM, Gazca GMO, López LSF (2011). Especies de árboles y arbustos frecuentes en la $2^{\circ}$ sección del bosque de Chapultepec [Frequent tree and shrub species in the $2^{\text {nd }}$ section of the Chapultepec Park]. Folleto técnico número 5, CENID, COMEF, INIFAP, México, pp. 52. [online] URL: http://areasverdesyarboladourb ano.com.mx/wp-content/publicaciones/Especie s-Frecuentes.pdf

Calderon De Rzedowski G, Rzedowski J (2005). Flora fanerogámica del Valle de México [Phanerogamic flora of the valley of Mexico] ( $2^{\text {nd }}$ edn). Instituto de Ecología, A.C. y Comisión Nacional para el Conocimiento y Uso de la Biodiversidad, Pátzcuaro Michoacán, México, pp. 1406. [in Spanish] [online] URL: http://www. biodiversidad.gob.mx/publicaciones/librosDig/p df/Flora_del_Valle_de_Mx1.pdf

Castillo-Argüero S, Martínez-Orea Y, Meave JA, Hernández-Apolinar $M$, Nuñez-Castillo $O$, Santibañez-Andrade G, Guadarrama-Chávez $P$ (2009). Flora: susceptibilidad de la comunidad a la invasión de malezas nativas y exóticas [Flora: community susceptibility to the invasion of native and exotic weeds]. In: "Biodiversidad del Ecosistema del Pedregal de San Ángel” (Lot A, Cano-Santana Z eds). Universidad Nacional Autónoma de México, México, pp. 538. [online] URL: http://www.repsa.unam.mx/documentos/ Castillo-Argüero_et_al_2009_flora_nativa_y_e xotica.pdf

Chacalo HA, Corona V (2009). Arboles y arbustos para ciudades [Trees and shrubs for cities]. Universidad Autónoma Metropolitana, México
City, Mexico, pp. 600. [in Spanish]

Chacalo HA, Grabinski J, Aldama A (1997). Site limitations for tree growth in Mexico City. In: Proceedings of the " 9 th Metropolitan Tree Improvement Alliance". Columbus (OH, USA) 8-10 Aug 1996. Ohio State University, Columbus, $\mathrm{OH}$, USA, pp. 47-52. [online] URL: https:// urbanforestrysouth.org/resources/links/metriaproceedings $-1 /$ ?searchterm=metria

Chiesura A (2004). The role of urban parks for the sustainable city. Landscape and Urban Planning 68: 129-138. - doi: 10.1016/j.landurbplan.20 03.08 .003

Clark J, Mathey NP, Cross G, Wake V (1997). A model of urban forest sustainability. Journal of Arboriculture 23 (1): 17-30. [online] URL: http:// naturewithin.info/Policy/ClarkSstnabltyModel.p df

CONAFOR (2007). Fichas técnicas elaboradas por el Sistema de Información para la Reforestación (SIRE) [Data sheets produced by the Reforestation Information System]. Paquetes tecnológicos, Comisión Nacional Forestal CONAFOR, México, pp. 245. [online] URL: http://www.cnf.gob.mx:809o/snif/portal/usos/fi chas-sire

Conway TM, Vander Vecht J (2015). Growing a diverse urban forest: species selection decisions by practitioners planting and supplying trees. Landscape and Urban Planning 138: 1-10. - doi: 10.1016/j.landurbplan.2015.01.007

Dávila FCA (2011). Estudio ecológico y biotecnológico del laurel (Litsea glaucescens) en Aguascalientes, México [Ecologic and biotechnological study of laurel (Litsea glauscescens) of in Aguascalientes, Mexico]. Master of Science Thesis, Centro de Ciencias Básicas, Universidad de Aguascalientes, Mexico, pp. 87. [in Spanish] [online] URL: http://hdl.handle.net/11317/919 Easterling DR, Meehl GA, Parmesan C, Changnon SA, Karl TR, Mearns LO (2000). Climate extremes: observations, modeling, and impacts. Science 289: 2068-2074. - doi: 10.1126/science. 289.5487.2068

Escobedo FJ, Kroeger T, Wagner JE (2011). Urban forests and pollution mitigation: analyzing ecosystem services and disservices. Environmental Pollution 159: 2078-2087. - doi: 10.1016/j.envpol. 2011.01.010

Gazca GMO, Benavides MMH (2012). Assay of leguminous trees for reforestation of the second section of Chapultepec Park. Revista Mexicana de Ciencias Forestales 3 (14): 39-54. - doi: 10.29298/rmcf.v3i14.473

GDF (2000). Manual técnico para el establecimiento y manejo integral de las areas verdes urbanas del Distrito Federal [Technical manual for establishment and integral management of urban green areas of the Distrito Federal]. Tomo I, Secretaría del Medio Ambiente y Gobierno del Distrito Federal, México, pp. 236. [in Spanish] [online] URL: http://centro.paot.org. $\mathrm{mx} /$ documentos/sma/manual_manejo_areas_v erdes_folleto_practico.pdf

GDF (2004). Restauración de áreas verdes del Distrito Federal [Restoration of urban green areas of the Distrito Federal]. Informe de avances del programa de sustitución de eucaliptos en condición de alto riesgo, México, Website. [in Spanish] [online] URL: http://centro.paot.org. $\mathrm{mx} /$ documentos/sma/restauracion areas verd 
es_df_eucalipto.pdf

González OML, Plascencia-Escalante FO, Martínez-Trinidad T (2016). Priority areas for ecological restoration and reference sites in Chignahuapan-Zacatlan region. Madera y Bosques 22 (2): 41-52. - doi: 10.21829/myb.2016.2221323 Guadarrama-Martínez N, Rubí-Arriaga M, González-Huerta A, Vázquez-García LM, Martínez-De la Cruz I, López-Sandoval JA, Hernández-Flores GV (2012). Inventory of trees and shrubs with ornamental potential in the southeast of the State of Mexico. Revista Internacional de Botanica Experimental 81: 221-228. [in Spanish with English abstract] [online] URL: http://www.revi staphyton.fund-romuloraggio.org.ar/vol81/32GUADARRAMA.pdf

Hardin PJ, Jensen RR (2007). The effect of urban leaf area on summertime urban surface kinetic temperatures: a Terre Haute case study. Urban Forestry and Urban Greening 6: 63-72. - doi: 10.1016/j.ufug.2007.01.005

Li YY, Wang XR, Huang CL (2011). Key street tree species selection in urban areas. African Journal of Agricultural Research 6 (15): 3539-3550. doi: 10.5897/AJAR11.461

López-Upton J, Valdez-Lazalde JR, Ventura-Ríos A, Hernádez-Vargas JJ, Guerra-De-la-Cruz V (2015). Extinction risk of Pseudotsuga Menziesii populations in the Central Region of Mexico: an AHP Analysis. Forests 6: 1598-1612. - doi: 10.339 o/f6051598

Malczewski J (1999). GIS and multicriteria decision analysis. John Wiley Inc., Ontario, Canada, pp. 392. [online] URL: http://books.google. com/books?id=2Zd54X4_2Z8C

Martínez GL (2008). Arboles y áreas verdes urbanas de la Ciudad de México y su zona metropolitana [Trees and urban green areas of Mexico City and its metropolitan area]. Fundación Xochitla, A.C. México, pp. 549. [in Spanish]

Miller RW (1997). Urban forestry - Planning and managing urban green spaces ( $2^{\text {nd }}$ edn). Prentice Hall, Upper Saddle River, NJ, USA, pp. 501. Mizerit TLH (2006). Situación y características del arbolado en las áreas verdes de las delegaciones Cuauhtémoc y Venustiano Carranza, Distrito Federal [Situation and characteristics of trees in urban green areas at the Cuauhtemoc and Venustiano Carranza boroughs, Distrito Federal]. Bachelor thesis, Facultad de Ciencias, UNAM, Mexico, pp. 77. [in Spanish] [online] URL: http://core.ac.uk/display/49037197

Morgenroth J, Ostberg J, Van Den Bosch CK, Nielsen $A B$, Hauer $R$, Sjöman $H$, Jansson $M$ (2016). Urban tree diversity - Taking stock and looking ahead. Urban Forestry and Urban Greening 15: 1-5. - doi: 10.1016/j.ufug.2015.11.003 Nielsen AB, Van Den Bosch M, Maruthaveeran S,
Van Den Bosch CK (2014). Species richness in urban parks and its drivers: a review of empirical evidence. Urban Ecosystems 17: 305-327. doi: 10.1007/s11252-013-0316-1

Niembro RA (1990). Arboles y arbustos útiles de México [Useful trees and shrubs from Mexico]. Editorial Limusa, México, pp. 206. [in Spanish] Olivas-Gallegos UE, Valdez-Lazalde JR, Aldrete A, González-Guillén MJ (2007). Suitable areas for establishing maguey cenizo plantations: definition through multicriteria analysis and GIS. Revista Fitotecnia Mexicana 30 (4): 411-419. [in Spanish with English abstract] [online] URL: http://www.redalyc.org/articulo.oa?id=6103040 8

Olmedo RLA, Rocha UO (2004). Sistema experto para la determinación de especies arbóreas nativas del Valle de México [Expert system for the determination of tree native species of the valley of Mexico]. Bachelor Thesis, División de Ciencias Forestales, Universidad Autónoma Chapingo, Mexico, pp. 55. [in Spanish] [online] URL: http://files.departamento-de-productos-fo rest.webnode.es/200001666-55925568bd/Olme doRodriguezLuisAntonioyRochaUgaldeOnesim 02004.pdf

Osorio GJC, Orejuela CJP (2008). Analytic hierarchic process and multicriteria decision making. Application example. Scientia et Technica 14 (39): 247-252. [in Spanish] [online] URL: http:// revistas.utp.edu.co/index.php/revistaciencia/ar ticle/viewFile/3217/1849

PAOT (2003). Manejo y conservación de áreas verdes. Informe anual [Management and conservation of urban green areas. Annual report]. Procuraduría Ambiental y del Ordenamiento Territorial - PAOT, DF, Mexico, Website. [in Spanish] [online] URL: http://paot.org.mx/cen tro/paot/informe2003/temas/manejo.pdf

Pauleit S (2003). Urban street tree plantings: identifying the key requirements. Proceedings of the Institution of Civil Engineers 156: 43-50. doi: $10.1680 /$ muen.2003.156.1.43

Rzedowski J, Calderón De Rzedowski G (2009). Lista preliminar de árboles silvestres del Estado de Guanajuato [Preliminary list of wild trees of the State of Guanajuato]. In: "Flora del Bajío y de Regiones Adyacentes” (Rzedowski J, Calderón De Rzedowski eds). Fascículo complementario XXIV, Instituto de Ecología, AC, Centro Regional del Bajío, Pátzcuaro, Michoacán, México, pp. 14. [in Spanish] [online] URL: http://www1. inecol.edu.mx/publicaciones/resumeness/FLOB A/ComplementarioXXIV.pdf

Rzedowski JG (2015). Catálogo preliminar de las especies de árboles silvestres de la sierra madre oriental [Preliminary catalogue of wild tree species from the Sierra Madre Oriental]. In: "Flora del Bajío y de Regiones Adyacentes"
(Rzedowski J, Calderón De Rzedowski eds). Fascículo complementario XXX, Instituto de Ecología, AC, Centro Regional del Bajío, Pátzcuaro, Michoacán, México, pp. 377. [in Spanish] [online] URL: http://inecolbajio.inecol.mx/flora delbajio/documentos/fasciculos/complementari os/ComplementarioXXXI.pdf

Saaty RW (1987). The analytic hierarchy process What it is and how it is used. Mathematical Modelling 9 (3-5): 161-176. - doi: 10.1016/0270-02 55(87)90473-8

Saaty TL (1990). How to make a decision: the analytic hierarchy process. European Journal of Operation Research 48: 9-26. - doi: 10.1016/037 7-2217(90)90057-I

Santamour FS (1990). Trees for urban planting: Diversity, uniformity and common sense. In: Proceedings of the $7^{\text {th }}$ Conference of the "Metropolitan Tree Improvement Alliance". Lisle (IL, USA) 11-12 June 1990. The Morton Arboretum, IL, USA, pp. 57-65. [online] URL: http://pdfs.se manticscholar.org/26a2/4c5361ce6d6e618agfa3 07c4a34a3169e309.pdf

SEMARNAT (2010). Norma oficial Mexicana NOM-059-SEMARNAT-2010 [Official Mexican standard NOM-059-SEMARNAT-2010]. Diario Oficial de la Federación (DOF), Secretaría de Medio Ambiente y Recursos Naturales - SEMARNAT, Mexico, Website. [in Spanish] [online] URL: http://dof.gob.mx/normasOficiales/4 254/semarnat/semarnat.htm

Simpson JR, McPherson EG (1997). Simulation of tree shade impacts on residential energy use for space conditioning in Sacramento. Atmospheric Environment 32 (1): 69-74. - doi: 10.1016/ S1352-2310(97)00181-7

Sjöman H, Nielsen AB (2010). Selecting trees for urban paved sites in Scandinavia - A review of information on stress tolerance and its relation to the requirements of tree planners. Urban Forestry and Urban Greening 9: 281-293. - doi: 10.1016/j.ufug.2010.04.001

Sæbø A, Benedikz T, Randrup TB (2003). Selection of trees for urban forestry in the Nordic countries. Urban Forestry and Urban Greening 2 (2): 101-114. - doi: 10.1078/1618-8667-00027 Ulrich RS (1986). Human responses to vegetation and landscapes. Landscape and Urban Planning 13: 29-44. - doi: 10.1016/0169-2046(86) 90005-8

Wang Y, Liu WY, Ko SH, Lin JC (2015). Tree species diversity and carbon storage in air quality enhancement zones in Taiwan. Aerosol and Air Quality Research 15: 1291-1299. - doi: 10.420 9/aaqr.2015.02.0110

Xiao Q, McPherson EG (2003). Rainfall interception by Santa Monica's municipal urban forest. Urban Ecosystems 6 (4): 291-302. - doi: 10.1023/ B:UECO.0000004828.05143.67 